\title{
PEMBELAJARAN SENI BUDAYA DAN KETERAMPILAN MENUMBUHKAN KECERDASAN MORAL SECARA KOMPETITIF
}

\author{
EningWidaningsih ${ }^{1}$
}

\begin{abstract}
ABSTRAK
Seni Budaya dan Keterampilan (SBK) sebagai salah satu bidang studi dalam pembelajaran dengan melihat latar belakang akan dapat menumbuhkan kecerdasan moral secara kompetitif, latar belakang tersebut sebagai berikut, yaitu bahwa muatan seni budaya dan keterampilan sebagaimana yang diamanatkan dalam peraturan Pemerintah Republik Indonesia Nomor 19 tahun 2005 tentang Standar Nasional Pendidikan tidak hanya dalam satu mata pelajaran karena budaya itu sendiri meliputi segala aspek kehidupan. Dalam mata pelajaran Seni Budaya dan Keterampilan, aspek budaya tidak dibahas secara tersendiri tetapi terintegrasi dengan seni. Karena itu mata pelajaran Seni Budaya dan Keterampilan pada dasarnya merupakan pendidikan seni yang berbasis budaya.Pendidikan seni budaya dan Keterampilan diberikan di sekolah karena keunikan, kebermaknaan, dan kebermanfaatan terhadap kebutuhan perkembangan peserta didik. Yang terletak pemberian pengalaman estetik dalam bentuk kegiatan berekspresi /berkreasi melalui pendekatan: "belajar dengan seni" "belajar melalui seni” dan "belajar tentang seni." Peran ini tidak dapat diberikan oleh mata pelajaran lain.
\end{abstract}

Kata Kunci: Pembelajaran Seni Budaya dan Keterampilan, Kecerdasan Moral, Siswa SD

\section{A. Pendahuluan}

Tidak dapat diragukan lagi betapa penting dan strategisnya pendidikan dalam pembangunan suatu bangsa. Pendidikan adalah investasi sumber daya manusia jangka panjang, yang mempunyai nilai strategis bagi kelangsungan peradaban manusia di dunia. Oleh sebab itu hampir semua Negara menempatkan variabel pendidikan sebagai sesuatu yang penting dan utama dalam konteks pembangunan bangsa dan negara. Begitu juga Indonesia menempatkan pendidikan sebagai sesuatu yang penting dan utama. Hal ini dapat dilihat dari isi Pembukaan UUD 1945 alinea IV yang menegaskan bahwa salah satu tujuan nasional bangsa Indonesia adalah mencerdaskan kehidupan bangsa. Dengan pendidikanlah seseorang dibekali dengan berbagai pengetahuan, keterampilan, keahlian dan tidak kalah pentingnya macam macam tatanan dalam kehidupan baik yang berupa norma - norma, aturan - aturan positif lainnya. Singkatnya pendidikan memungkinkan menjadikan manusia seutuhnya baik secara lahiriah maupun batiniah. Proses pendidikan terjadi pada jenjang jenjang pendidikan dan mengacu pada kurikulum sesuai dengan jenjang jenjang pendidikan

\footnotetext{
${ }^{1}$ Dosen PGSD UPI Kampus Cibiru
} 
tersebut, proses pendidikan melibatkan kegiatan / proses belajar mengajar pada kegiatan belajar mengajar tersebut guru menjadi kuncinya (key person).

Siapapun tidak akan pernah menyangkal bahwa kegiatan belajar mengajar tidak berproses dalam kehampaan, tetapi dengan penuh makna Kegiatan belajar mengajar adalah suatu kondisi yang dengan sengaja diciptakan gurulah yang menciptakannya guna membelajarkan siswanya, guru yang mengajar dan siswa yang belajar perpaduan dari kedua unsur manusia ini lahirlah interaksi edukatif dengan memanfaatkan bahan bahan sebagai mediumnya. Sebagai guru sudah menyadari apa yang sebaiknya dilakukan untuk menciptakan kondisi belajar mengajar yang dapat mengantarkan siswa ke tujuan yang mampu menumbuhkan kecerdasan moral secara kompetitif. Kecerdasan merupakan sikap intelektual mencakup ketepatan memberikan jawaban, penyelesaian dan kemampuan memecahkan masalah (Munzert, A.W. (1994). Kecerdasan tidak hanya dipahami sekedar sebagai intelektual (IQ) tetapi juga kecerdasan emosional (EQ), kecerdasan sosial (SQ), dan sebagainya (RadnoHarsanto, 2007: 24). David Wescher memberikan rumusan kecerdasan sebagai suatu kapasitas umum dari individu untuk bertindak, berpikir rasional dan berinteraksi dengan lingkungan secara efektif.

Hakikat belajar mengajar dalam kegiatan belajar mengajar anak sebagai subjek dan objek dari kegiatan pengajaran karena itu inti proses pengajaran tiada lain adalah kegiatan belajar anak didik dalam mencapai suatu tujuan pengajaran. Tujuan pengajar tentu saja akan tercapai jika anak berusaha aktif mencapainya. Keaktifan anak disini tidak hanya dituntut dari segi fisik tetapi dari segi kejiwaan, bila hanya fisik yang aktif tetapi pikiran dan mentalnya kurang aktif maka kemungkinan besar tujuan pembelajaran tidak akan tercapai. Ini sama halnya dengan anak didik tidak belajar, karena anak didik tidak merasakan perubahan dalam dirinya. Padahal belajar pada hakikatnya adalah "perubahan" yang terjadi pada seseorang setelah berakhirnya melakukan aktivitas belajar. Sama halnya dengan belajar, mengajar pun pada hakikatnya adalah suatu proses yaitu proses mengatur, mengorganisasi lingkungan yang ada sekitar anak sehingga dapat menumbuhkan dan mendorong anak didik melakukan proses belajar. Pada tahap berikutnya mengajar adalah proses memberikan bimbingan / bantuan kepada anak didik dalam melakukan proses belajar.(Nana Sudjana1991:29). Akhirnya bila belajar adalah "perubahan”, maka hakikat belajar mengajar adalah prosesditandai dengan aktivitas anak didik sebagai konsekuensi bahwa anak didik merupakan syarat mutlak bagi berlangsungnya kegiatan belajar mengajar, peran guru sebagai pembimbing harus memotivasi “ pengaturan’ yang dilakukan guru.

Komponen komponen belajar mengajar, sebagai suatu sistem tentu saja kegiatan belajar mengajar mengandung sejumlah komponen antara lain yang meliputi tujuan,adalah suatu cita cita yang ingin dicapai dari pelaksanaan suatu kegiatan; bahan pelajaran,adalah substansi yang akan disampaikan dalam proses belajar mengajar; kegiatan belajar mengajar, adalah kegiatan inti dalam pendidikan, dalam tersebut akan melibatkan semua komponen pengajaran kegiatan belajar akan menentukan sejauh mana tujuan yang telah ditetapkan telah tercapai; metode, adalah 
suatu cara yang dipergunakan untuk mencapai tujuan; alat adalah segala sesuatu yang dapat digunakan dalam rangka mencapai tujuan pengajaran alat dibagi dalam dua macam yaitu alat dan alat bantu pengajaran atau alat material \&nonmaterial; sumber belajar adalah segala sesuatu yang dapat digunakan sebagai tempat dimana bahan pengajaran terdapat atau asal untuk belajar seseorang (Udin SyaripuddinWinataputra :1991); serta evaluasi, adalah suatu tindakan / proses untuk menentukan nilai sebagai sesuatu dalam pendidikan / segala sesuatu yang ada hubungannya dengan pendidikan.

Ciri ciri belajar mengajar sebagai suatu proses pengaturan kegiatan belajar mengajar tidak terlepas dari ciri-ciri tertentu menurut Edi Suardi sebagai berikut: 1) belajar mengajar memiliki tujuan yakni membentuk anak didik dalam suatu perkembangan tertentu, 2) ada suatu prosedur (jalannya interaksi) yang direncanakan, didesain untuk mencapai tujuan tertentu, 3) ditandai dengan satu penggarapan materi yang khusus, 6) dalam kegiatan belajar mengajar membutuhkan disiplin, disiplin dalam kegiatan belajar mengajar diartikan sebagai suatu pola tingkah laku yang diatur sedemikian rupa menurut ketentuan yang sudah ditaati, 7) ada batas waktu, untuk mencapai tujuan pembelajaran tertentu batas waktu menjadi salah satu yang tidak bisa ditinggalkan. Setiap tujuan akan diberi waktu tertentu kapan tujuan itu sudah kegiatan diatas masalah evaluasi bagian yang tidak bisa diabaikan setelah melaksanakan kegiatan belajar mengajar evaluasi harus dilakukan untuk mengetahui tercapai tidaknya tujuan pengajaran yang telah ditentukan

Keberhasilan belajar mengajar untuk menyatakan bahwa suatu proses belajar mengajar dapat dikatakan berhasil sebaiknya kita berpedoman pada kurikulum yang berlaku saat ini antara lain " Suatu proses belajar tentang suatu bahan pengajaran dinyatakan berhasil apabila tujuan instruksional khusus (tik) -nya dapat tercapai”.

Arti dan makna pembelajaran, pembelajaran adalah membelajarkan siswa menggunakan asas pendidikan maupun teori belajar merupakan penentu utama keberhasilan pendidikan. Pembelajaran merupakan proses komunikasi dua arah mengajar dilakukan oleh pihak guru sebagai pendidik, sedangkan belajar dilakukan oleh peserta didik.Konsep pembelajaran menurut Corey ( 1986:195) adalah suatu proses dimana lingkungan seseorang secara disengaja dikelola untuk memungkinkan ia turut serta dalam tingkah laku tertentu dalam kondisi kondisi khusus atau menghasilkan respons terhadap situasi tertentu, pembelajaran merupakan subset khusus dari pendidikan Pembelajaran mengandung arti setiap kegiatan yang dirancang untuk membantu seseorang mempelajari suatu kemampuan dan atau nilai yang baru. Untuk memahami lebih mendalam pembelajaran menurut Dimyati Mudjiono (1999: 297) kegiatan guru untuk secara terprogram dalam desain instruksional, untuk membuat siswa belajar secara aktif, yang menekankan pada penyediaan sumber belajar. UUSPN No. 20 tahun 2003 menyatakan pembelajaran adalah proses interaksi peserta didik dengan pendidik dan sumber belajar pada suatu lingkungan belajar. Pembelajaran sebagai proses belajar yang dibangun oleh guru untuk mengembangkan kreativitas berpikir yang dapat meningkatkan kemampuan berpikir siswa, serta dapat meningkatkan kemampuan mengonstruksi pengetahuan baru sebagi upaya meningkatkan penguasaan yang baik terhadap materi pelajaran. 
Pembelajaran mempunyai dua karakteristik yaitu; pertama dalam proses pembelajaran melibatkan bukan hanya menuntut siswa sekedar mendengar, mencatat, akan tetapi menghendaki aktivitas siswa dalam proses berpikir. Kedua, dalam pembelajaran membangun suasana dialogis dan proses tanya jawab terus menerus yang diarahkan untuk memperbaiki dan meningkatkan kemampuan berpikir siswa, yang pada gilirannya kemampuan berpikir itu dapat membantu siswa untuk memperoleh pengetahuan yang mereka konstruksi sendiri.

Kecerdasan sebagai salah satu tujuan pembelajaran hal ini sesuai dengan tujuan pendidikan nasional dalam UUSPN (UU No. 2 tahun 1989), berbunyi” Pendidikan nasional bertujuan mencerdaskan kehidupan bangsa dan mengembangkan manusia Indonesia seutuhnya, yaitu manusia yang beriman dan bertakwa terhadap Tuhan Yang Esa yang berbudi luhur, memiliki pengetahuan dan keterampilan, kesehatan jasmani dan rohani, kepribadian yang mantap dan mandiri serta rasa tanggung jawab kemasyarakatan dan kebangsaan”.

Kecerdasan tidak dipahami sekedar kecerdasan intelektual (IQ), tetapi juga kecerdasan emosional (EQ), kecerdasan sosial (SQ) dan dan sebagainya. Howard Garner (1993) memperkenalkan multipleintelegences (kecerdsan jamak), yakni visual/ spatialintelligence, verbal/ linguisticintelligence, logical/ mathematicalintelligence, bodily / kinestheticintelligence, musical/ rhythmicintelligence, interpersonal intelligence, intrapersonal intelligence, dannaturalishintelelligence. (RadnoHarsanto, 2007:24). UNISCO pada tahun 1996 melalui Komisi Internasional untuk Pendidikan Abad 21 menyarankan diterapkannya empat pilar belajar (Soedijarto, 2006) salah satu pilar diantaranya yaitu learningto do, sasaran akhir dari diterapkannya pilar ini adalah lahirnya generasi muda yang dapat bekerja secara cerdas dengan memanfaatkan Iptek.

\section{B. Pembelajaran Seni Budaya dan Keterampilan}

Seni Budaya dan Keterampilan (SBK) sebagai salah satu bidang studi dalam pembelajaran dengan melihat latar belakang akan dapat menumbuhkan kecerdasan moral secara kompetitif, latar belakang tersebut sebagai berikut, yaitu bahwa muatan seni budaya dan keterampilan sebagaimana yang diamanatkan dalam peraturan Pemerintah Republik Indonesia Nomor 19 tahun 2005 tentang Standar Nasional Pendidikan tidak hanya dalam satu mata pelajaran karena budaya itu sendiri meliputi segala aspek kehidupan. Dalam mata pelajaran Seni Budaya dan Keterampilan, aspek budaya tidak dibahas secara tersendiri tetapi terintegrasi dengan seni. Karena itu mata pelajaran Seni Budaya dan Keterampilan pada dasarnya merupakan pendidikan seni yang berbasis budaya.

Pendidikan seni budaya dan Keterampilan diberikan di sekolah karena keunikan, kebermaknaan, dan kebermanfaatan terhadap kebutuhan perkembangan peserta didik. Yang terletak pemberian pengalaman estetik dalam bentuk kegiatan berekspresi /berkreasi melalui pendekatan: "belajar dengan seni" "belajar melalui seni” dan "belajar tentang seni." Peran ini tidak dapat diberikan oleh mata pelajaran lain. 
Pendidikan Seni dan Budaya dan Keterampilan memiliki sifat multilingual multidimensional,dan multipengembangan kemampuan mengekspresikan diri secara kreatif dengan berbagai cara dan media seperti bahasa rupa, bunyi, gerak, peran dan berbagai perpaduannya. Multidimensional bermakna perkembangan beragam kompetensi meliputi konsepsi (pengetahuan,pemahaman, analisis,evaluasi), apresiasi, dan kreasi dengan cara memadukan secara harmonis unsur estetika, logika, kinestetika, dan etika. Sifat multikultur mengandung makna pendidikan seni menumbuhkembangkan kesadaran dan kemampuan apresiasi terhadap beragam budaya Nusantara dan Mancanegara. Hal ini merupakan wujud pembentukan sikap demokratis yang memungkinkan seseorang hidup secara beradab serta toleran dalam masyarakat dan budaya yang majemuk.

Pendidikan Seni Budaya dan Keterampilan memiliki peranan dalam pembentukan pribadi peserta didik yang harmonis dengan memperhatikan kebutuhan perkembangan anak dalam mencapai multikecerdasan yang terdiri atas kecerdasan intrapersonal, interpersonal, visual spasial, musikal, linguistik, logikamatematika, naturalis serta kecerdasan adversitas, kecerdasan kreativitas, kecerdasan spiritual dan moral, dan kecerdasan emosional.

Bidang Seni Rupa, musik, tari, dan keterampilan memiliki kekhasan tersendiri sesuai dengan kaidah keilmuan masing-masing. Aktivitas berkesenian harus menampung kekhasan tersebut yang tertuang dalam pemberian pengalaman mengembangkan konsepsi, apresiasi, dan kreasi. Semua ini diperoleh melalui upaya eksplorasi elemen, prinsip, proses, dan teknik berkarya dalam konteks budaya masyarakat yang beragam. Karakteristik belajar siswa seperti kita ketahui bersama pertama karakteristik kognitif yang berhubungan dengan cara berpikir yang has, kedua karakteristik psikomotor berhubungan cara bertindak yang has. Ketiga karakteristik afektif yaitu cara cara yang has dalam merasakan atau mengungkapkan emosi.

Siswa dalam bernalar termasuk pada bidang seni dan keterampilan tentu beragam tetapi setidaknya terjadinya proses kegiatan belajar dalam ranah afektif dapat diketahui dari tingkah siswa yang menunjukkan adanya kesenangan belajar. Perasaan, emosi, minat, sikap, dan apresiasi yang positif yang menimbulkan tingkah laku yang yang konstruktif dalam diri belajar (Anderson 1981)

\section{Pentup}

Guru sebagai key person dalam proses pembelajaran tentu dituntut kemampuannya / kompetensi untuk melakukan tugas, dalam pembelajaran, tersebut, secara professional. dapat mewujudkan kinerjanya secara tepat dan efektif. Kompetensi sebagai pengetahuan atau keterampilan dan nilai nilai dasar yang direalisasikan dalam kebiasaan berpikir dan bertindak (Finch dan Crunkilton dalam E. Mulyasa, 2003);

Dengan profesionalisme guru tidak tampil sebagai pengajar saja tetapi sebagai pelatih (coach), sebagai pelatih ia memotivasi siswanya untuk bekerja keras dan mencapai prestasi setinggi tingginya dan membantu siswa menghargai nilai belajar 
dan pengetahuan; Sebagai pembimbing (counselor), guru berperan sebagai sahabat siswa, menjadi teladan dalam pribadi yang mengundang rasa hormat dan keakraban dari siswa dan manajer belajar (learningmanager), sebagai manajer kelas membimbing siswa belajar, mengambil prakarsa, dan mengeluarkan ide ide yang dimilikinya. Dengan ketiga peran tersebut diharapkan dapat menumbuhkan kecerdasan moral siswa secara kompetitif. Wal'llahua'lambis-shawab

\section{DAFTAR PUSTAKA}

Ali, M. (2000) Guru dalam Proses Belajar Mengajar. Bandung: PT Sinar Baru Algesindo

Arends, R.A. (2008) LearningtoTeach:Belajar untuk Mengajar. Yogyakarta: Pustaka Pelajar.

Arikunto, S. 1993 Manajemen Secara Manusia. Jakarta: PT Rineka Cipta. Pengelolaan Kelas dan Siswa Jakarta: CV RajaWali

Djamarah, S.B. dan Zain, A. (2006) Strategi Belajar Mengajar. Jakarta: Rineka Cipta

Hadari, N. (1992) Organisasi Sekolah dan Pengelolaan Kelas Jakarta: Gunung Agung

Harsanto, R. (2007) Pengelolaan Kelas yang Dinamis: Paradigama Baru Menuju Kompetensi Siswa. Yogyakarta: Kanisius.

Mulyasa, E. (2004) Menjadi Kepala Sekolah Profesional Dalam Konteks Menyukseskan MBS dan KBK. Bandung: PT Remaja Rosdakarya

Suryosubroto (2004) Manajemen Pendidikan di Sekolah Jakarta: PT Rineka Cipta

Undang Undang Republik Indonesia No. 14 Tahun 2005 tentang Guru dan Dosen

Undang Undang Republik Indonesia No. 20 Tahun 2003 tentang Sistem Pendidikan Indonesia

Zaini, H., Munthe, B., dan Aryani, S.A. (2004) Strategi Pembelajaran Aktif Diterbitkan: CTSD

Zuchdi, D. (2009) Humanisasi Pendidikan: Menemukan Kembali Pendidikan yang Manusiawi. Jakarta: Bumi Aksara. 